\title{
The dairy goat introduction to the neotropical savannas of N.E.-Venezuela: a five years (2010-15), rewarding experience
}

\begin{abstract}
Hereby the innovative introduction of the goat (Capra hircus), as a sustainable small ruminant dairy goat entrepreneurship to the Neo-tropical "Mesa de Sabana" (high savanna), Biome, of Northeastern Anzoategui-Venezuela, is technically described. The goat agro-ecological entrepreneurship, is described, over its first five (5), years (2010-15), of operation, since the first "native goats" were introduced (2009), to "Curareque Urica Arriba", an old traditional "Hato L Lanero Oriental" (Typical Venezuelan N.E.-Plain-Land Cow \& Horse Farm/XIX Century). This methodological descriptive article (paper), summarizes the "vet's-farmer", experiences and new goat behaviour (ethological), learning's, as an innovative (historical-sociocultural), commercial entrepreneurship "cabra leche sabana", is on its sustainable starts, at the Northeastern Anzoategui, Venezuelan "Llanos" (savanna plain lands).
\end{abstract}

Keywords: neo-tropical savanna, dairy goats, anzoategui, venezuela, sabana, rangeland, pastoral grazing system
Volume 7 Issue 6 - 2018

\section{Mario H Burguera}

Finca-Capril Curareque, Curareque Dairy Goat Farm, Venezuela

Correspondence: Mario H Burguera, Finca-Capril Curareque, Freites, Anzoátegui-Venezuela, Curareque Dairy Goat Farm, Venezuela, Email caprinawta@gmail.com

Received: September 21, 2016 | Published: November 21, 2018

\section{Methodology}

\section{The N.E-ANZ savanna site}

Our present@Cabra Leche Sabana experience takes place in the plain lands ${ }^{1}$ of Nor. East-Venezuela, South America, at a wide natural area of neo-tropical savannas. The specific local site, is an old XIX century cattle ranch (Hato Llanero), "Curareque Urica Arriba", of the north-eastern Anzoátegui state, with its typical Biome- Ecotone, of high (250-300mts), plain lands of varied natural grassland vegetation, predominantly of the Tachypogon ${ }^{2}$ Andropogon, and Setaria native grass species. The typical native tree species of these Anzoátegui's "Chaparral" savannas are of the fire resistant species: Curatella American ("Chaparro"), Bowditch virgiliodes ("Alcornoque"), and Brysonima crassifolia ("Chaparro Manteco"), scatter all over the plain grassland areas, or in busy cluster of forest vegetation, usually at the better soil-water sites, protected from the risk of the annual fires. Among Botanical specialist, the common opinion is that our savannas are of an anthropological (human), origin. The result of the old sociocultural use of the fire for hunting practices of the native inhabitants, together with the new disturbances, brought by civilization and its modern agricultural and oil exploitation practices. ${ }^{2}$ Our neo/tropical Mesa de Sabana plain lands are of a younger geo-physiological formation age (Paliolitic Origen), than the 'old world' better known African Savannas. Having good tropical bio-diverse vegetation of dry forest (Hold ridge), with abundant small-life (insects), and microscopic fungal-bacterial fauna; but without the large wild-animals diversity of the older African Savannas. The general climate and rains of the area are typical of a geographical dry monzonic zone, with a main rain period ("invierno"), of 4-6months, where $70-75 \%$ of the annual 850 $1200 \mathrm{~mm}$ rainfall is recorded. The dry period ("verano"), usually occurs between December and April each year, with May and November as intermediate months period. The year round temperature fluctuates on the $22-30 \mathrm{C}$ range, with a very windy period, at the "verano", helping mitigate the day's inclement temperature. ${ }^{3}$ The climate of the windy dry period at our high table savannas ("sabanas de mesa"), is quite similar to that of other world desert zones, having very hot sunny days with cold windy nights.

\section{Venezuela's tropical goats}

Before the European-Spaniard's first "discovery arrival", to the new world "America" our continent didn't know of the horse, cow, goat-sheep, and neither of the house dog or any backyard poultry. ${ }^{4}$ For our early native indigenous America's inhabitants, the only large ruminant they knew was the wild bison of temperate North American natural prairies. And as for the small ruminant species, we only had, all over north, central and south America's, the white tail deer (Odocoileus virginiatus), on the wild. After Colon's 1492-3, last voyages, and during the whole XV century of the European Conquerors and Church Missionaries, advance inland America's territories; the early genetic foundational of our today "America's Tropical Goat". Was introduced from the caprine gene stock (North Africa, Mediterranean islands, Spain-Portugal), the Europeans knew and had access during their long sea travels to America. From this early genetics, the European Mediterranean goat started a long survival-adaptation period to its America's new home. Given raise (creating), during the XX century, in North America by improved animal management and reproductivegenetics, ${ }^{5}$ some of the new goat breeds we now know as: the Southern California Lamancha, the Texas Savanna, and Tennesse Miotonic (fainting) Goats. At the other side, at our underdeveloped South of America, the original European goat now well adapted (tropicalized), and colloquially called "chivos", all over Latin America, remained and still can be found today: "at almost a natural semi-wild state" (MHB dixit), browsing in marginal-degraded semiarid and arid lands,", usually poorly managed in extensive communal systems. ${ }^{6}$ For our Curareque "cabra leche sabana" entrepreneurship initial start (2009), we precisely locked for these native ("criollo"), goats, closely 
selecting for good tropical adaptation, reproductive soundness, and abilities to periodically care and wean offspring. After year 2010, in line with our early vision and improvement objectives of the "Modelo Caprino Lechero Tecnificado" (Technified Dairy Goat Model). ${ }^{7}$ For the dairy reorientation of the initial meat oriented stock, we have since being introducing milk genes from selected males of the Saanen, Toggenburg, Alpine, and Majorero dairy goat breeds.

\section{Our "sabana" goat pasturing system}

For our "cabra leche sabana" project, on the old well conserved savannas of Curareque, we decided to focus on an agro-ecologically model as our goat system. ${ }^{8}$ Managing the new arrived small ruminant herd under a semi-extensive cattle pastoral system, like the one traditionally used on the old cow ranches ${ }^{9}$ of northeaster and south Venezuela. Under this "more friendly" animal-environmental system, the animals are milked only once a day, usually very early morning at their corrals, and then let free all day long for their free daily grazing, keeping home only the lactating offspring. The mother cows/goats have access to the rangeland native vegetation of the open savanna, or graze in large fenced paddocks areas of introduced pastures. ${ }^{10}$ They return back home, usually after late afternoon (PM), to water and nurse their calves, staying during all the night, confined in their corrals, before next day hand milking. For the small browser-forager, more human social goat, this semi confinement savanna system has worked perfectly well until now, helped by the zone well conserved ecosystem of high-dry soils, water and plenty bio-diverse ruminant's feed availability. The open range area available for free grazing the goats, ${ }^{11}$ 250 Has plain lands around the house with good farm infrastructure; is of natural vegetation with introduced Brachiaria brizantha, ${ }^{12}$ Panicum maximum, Digit aria decumbent and Andropogon gayanus, improved grass species. Off these half off the area (100 Has), is well fenced with native tree live-fences and alleys, of spiny Fagara sp, Cactus opuntia, and Pereskia guamacho. ${ }^{13}$

\section{Results and discussion}

Within our bio-diverse neo-tropical savanna environment, working agro/ecologically, with a small browser-grazer ruminant as the goat, we had no doubts for our project's start base, relaying on a "silvo-pastoral" 14 free grazing system. And therefore our first expected caprice ethological learning's had to be related to the goat's behavioural adaptation to their new savanna biome. The nearby, N.E-Anzoategui, bushy zone from where the goats came from, is quite a dry area, to the best of our knowledge, "a marginaldeteriorated agro-ecological zone", as compared with the ecosystem "Mesa de Sabana", the new goat's home, of the animals. During their first introduction year (2015), the goats paid no attention to graze the taller, well conserved grass species: Brachiaria, Panicun and Andropogon, previous introduced pastures of the early eighties cattle exploitation farm..$^{15}$ The new arrived goats also paid little attention for the native grass Trachypogon sp. nor the natural legume Stlylosantes guayanensis ${ }^{16}$ and Mimosa pudica, the more abundant species, on site. Initially for their pasturing the goats preferred to browse scrubs and graze the prostrate: Digit aria swazilandensi-“swazi", and Digit aria decumbent-"pangola". Clear for us, was the goat's initial behaviour to browse along the scattered cactus and busy vegetation of the farm's live-fences, and to defoliating the native scrubs Sida $\mathrm{sp}^{17}$ and the Spiny Amaranthus (Pira) ${ }^{18}$ species quite common at the dry bushy areas where the animals came from. But our really great surprise (learning), came from the goats eagerly looking for the Fagara $\mathrm{sp}^{19}$ the main native tree species of the live-fences and pasture alleys at Curareque. These spiny native tree was early introduced (1970), by our parent generation for their old cattle ranch live-fences together with the "Guamache". ${ }^{20}$ since these 2 trees due to their sticky bio-architecture (branch spines), was not eaten nor disturbed at all, by the cows and the other large animals (horses), the old farm had. Upon their arrival to their new site, "Curareque", the bush bought "criollo" (native), goats, were kept in quarantine, in the large "patios" (house yard), fenced areas, long ago planted with the fruit trees Mango (Manguifera indica), Mamon (Melicoccus bijugatus), Cereza (Malphiguia glabra), and Merey (Anacardiun occidentalis). During their first month yard confinement, the goats were offered care, shelter and good Swazi and Bermuda hay, as their main dietary forage supply. During their long (3 months).' hold on period', the goats were eagerly seen browsing all the house patio greens, and the tree branches and green leaves at their reach, as well as all the fallen fruits and dry leaves they could find. Also as part of the "Cereza", tree's trunk, at their reach, endangering the plant's future life. After the adaptation-quarantine 3 month period, the goats were allowed to graze free on the open savanna lands (250Has), around the farm's house and cattle corrals. For their initial rangeland grazing the animals were closely followed (observed), day long, as a unified goat herd, by a "llanero" (cowboy), on his horse. ${ }^{21}$ During these open savanna browsing-grazing the goats clearly showed (literature cited), their known biological grass feeding behaviour of pasturing for 2-3hours morning, ${ }^{22}$ rest-ruminate ( $2 \mathrm{hrs}$ ), usually at mid-day, and then re-start feeding again for the remaining 2-3dayhours before returning home, 4-5PM around. From our initial field observations the duration of this goat bimodal 2-3hours pasturing/ period, was dependent on the year/period availability (abundance), of the vegetation at the savanna ${ }^{23}$ pasturing area. During the dry months of the year ("verano"), with dry-mature (scarce) vegetation, the animals tended to spend a much longer time pasturing. Also during the wet season ("invierno"), the "water-afraid' goats pastured for less time on the cloudy, rainy or water spell days. At the Curareques savanna rangelands, the goats also found on their graze-browse behaviour, ${ }^{24}$ other "delightful feed trees", as the "Aceite" (Prosophis juliflora), "Guamache" (Pereskia guamacho), "Caruto" (Genipa Americana), "Jobo" 25 (Spondias mombin), and the "Guasimo" (Guazuma ulmifolia). All these trees found on the intermediate savanna busy areas, seasonally at different year/times, defoliate, flower and have fruits usually at the "invierno-verano" transitional months of MarchApril. Providing the animals with an excellent, ${ }^{26}$ usually high protein, natural dietary supplement. After the first one year of goat's savanna grazing field observations, and keeping in line with the environmental-economic entrepreneurship vision of our "cabra leche sabana" agro-technified model. We decided to re-introduce, ${ }^{27}$ as an ecological savanna management tool, the "candela" or a controlled fire within our goats free grazing savanna system. For this we relied on rational combining the 'seasonal fire tool' traditionally used by the old "llaneros" on their ancestral knowledge of the "llanos" their vegetation and the within years climate ${ }^{28}$ combined with the most modern agro-ecological savanna soil-vegetation ${ }^{29}$ conservative methods, now a day's web-internet and scientific literature available. With the controlled use of the fire on timely selected savanna patches, ${ }^{30}$ of the goats grassing lands at Curareque; the first achievement we got, together with mild fertilization, was the recovery of the 50 has of the old Brachiaria sp, well live-fenced paddocks, ${ }^{31}$ strategically located near the ranch's house-corrals. At years 2012-13, upon the fire rational use, and fertilization of the Brachiaria's paddocks; the goats started paying attention to graze this improved cattle grass. ${ }^{32}$ making 
us aware, not only of the small ruminant's introduced pasture feeding potential. But also of the danger of the animals' overgrazing the better paddock areas, on a savanna rangeland, not well managed goat free grazing system.

\section{Comments}

With the experiences gained during the first five (2010-15), years of our savanna dairy goat entrepreneurship at Curareque N.EAnzoátegui, we are now rewarded with a better understanding off the dairy goats and their agro-ecological savanna grazing behaviour, under the sustainable model we early designed for our technified "Modelo Caprino Lechero" project. The "criollo", native goats, we started upon, at 2009, and now their F1 and F2 up-going dairy improved generations, are doing well making the most ample use of the native and introduced (grass, legume, tree) of Anzoátegui's neo-tropical savanna vegetation. And we have re-discovered the modern role "a good technical oriented dairy goat savanna system" (MHB dixit), can have for Venezuela XXI century, agro-alimentary-production, and its rural-s people social-economic welfare. For us, on the more agroprofessional-academic fields, we are very proud with our "criollo", goats "discovery", of the great feeding value of a native savanna spiny tree colloquially known in our area as the "Mapurite blanco", This tree of ample tropical distribution from south USA, Central-America and Colombia-Venezuela is a citrus related Euphorbiaseae family tree, modern botanically called Fagara specie. Upon personal consulting and literature review our Mapurite blanco (US "Cats Claw", Mexico "Limoncillo"), seems to be the Fagara monocitophylia tree. With an excellent bromathological profile as a safe high protein fodderforage ruminant feed. With the extra gastronomic value for our entrepreneurship, coming from the natural "citrus taste", that this supplementary feed, gives to our natural artisanal goat milk products.

\section{Conclusion}

Under Venezuela's present (2016), socio-economic realities, together with the world's climatological-human alimentary 'grim forecasts', for the mid (2030-50), XXI Century. From our “@ CabraLecheSabana", 5 years initial experiences, with a neo-tropical savanna - goat introduction project.

For our "new South-America world", can early conclude (MHB dixit), that our savanna dairy goat model could be part of positive answers, to buster the integral agro-ecological-social and economic development potentials of:

I. The large marginal (un-used), neo-tropical savanna plain lands of Brazil, Colombia, Venezuela and Surinam/South-America

II. Break with old tropical goat negative paradigms and the many misconceptions until now associated with dairy goat sustainability

III. Incorporate an 'agro-technically educated', small rural-farmer, well integrated within small ruminant's meat \& milk value chains and markets.

\section{Acknowledgements}

None

\section{Conflict of interest}

The author declares that there is no conflict of interest.

\section{References}

1. Ramia M. Tipos de sabanas en los llanos de Venezuela. 1967;26(112):264-288.

2. Claure Espinosa D. Variaciones estacionales de los constituyentes bromatologicos de la paja peluda Trachypogon plumosus. Acta Botanica Vnzlna. 1969;4(1):389-421.

3. Aharon H, Henkin Z, Ungar ED, et al. Foraging behavior of the newly introduced Boer goat breed in a Mediterranean woodland: A research observation. Small Ruminant Research. 2007;69(1):144-153.

4. Rangeland goat production in western NSW. Department of Primary Industries. 2012.

5. Bartolome J, Franch J, Plaixats J, et al. Diet selection by sheep and goats on Mediterranean heath woodland Range. Journal of Range Management Archives. 1998;51(4):383-391.

6. Chacon P. Produccion y dinamica de la material organica en una sabana de Trachypogon al sur del Edo Guarico. Univ Nac Exp Simon Rodriguez-VL Pascua. 1986.

7. Celaya R., Jauregui BM, Garcia RR, et al. Changes in heath land vegetation under goat grazing: effects of breed and stocking rate Applied Vegetation Science. 2010;13:125-134.

8. Coplanarh. Inventario Nacional de Tierras: Region Centro-Oriental y Oriental. 1974

9. Devendra C, Burns M. Goat production in the Tropics. 1983.

10. Downing BH, Evans JC. A survey approach to evaluate the effects of management on the semi-arid and arid lands of New South Wales. 1989.

11. Du Plessis J, Van Der Waal, Webb EC. A comparison of plant form and browsing height selection of four small stock breeds- preliminary results South African. Journal of Animal Science. 2004;34(5):31-34.

12. Ganskopp D, Richman L, Johnson D, et al. Preferences of Angora goats for eight selections of grasses used for reclamation of Great Basin Rangelands. Small Rum Research. 1996;19(2):103-112.

13. Guide to Starting a Commercial Goat Dairy. 2012

14. Guide to Native Pasture Management. 2017

15. Grunwaldt JC, Pedrani AR, Vich AI. Goat grazing in the arid piedmont of Argentina. Small Ruminant Research. 1994;13(3):211-216.

16. Hacker RB, Clipperton S, Melville G. Role of goat production as a rangeland recovery alternative enterprise. Final Report to WEST 2000 Plus. 2005.

17. Hart SP, BR Min. Forage Based Dairy Goat Management. Goat Field Day, Langston University, Langston. 2002;36-40.

18. Hernabdez Hernandez RM, Choros R, Bravo Medina CA, et al. La integración del conocimiento local y científico en el manejo sostenible de las sabanas. Dialnet. 2011;36(2):104-112.

19. Johnson WL, Van Eys JE, HA Fitzhugh. Sheep and Goats in Tropical and Subtropical Agricultural Systems. Journal of Animal Science. 1986;63(5):1587-1599.

20. Lemus R, Brown K. Feeding small ruminants: developing a grazing system for sheep and goats. Mississippi State University. 2008.

21. Sanchez PA. Advances in the management of oxisols and ultisols in tropical South America. International seminar in Soil Environment and Fertility Managment in Intensive Agriculture. 1977.

22. Onokpise OU, McKenzie Jakes A, Whilby L, et al. Goats among Trees a Silvopastoral Possibility. Univ of Florida. 2012. 
23. Pittier H. La Mesa de Guanipa Ensayo de Fito-Geografia. 1942.

24. Rafig MK, Afzal J, Jasra AW, et al. Foraging preferences of free ranging sheep and goats on the native vegetation of rangelands of Pubbi HillPakistan. Journal of Agriculture and Biology. 2010.

25. Ramirez RG. Feed resources and feeding techniques of small ruminants under extensive management conditions. Small Ruminant Research. 1999;34(3):215-230

26. Ramia M. Plantas de las sabanas llaneras. 1974.

27. Ramia M. Ecologia de las sabanas del Edo Cojedes. Relaciones vegetación-suelo en sabanas secas. 1993.

28. Merkel RC. Strategies for Sheep and Goat Feeding and Management during Drought. Technical Bulletin Ethiopia Sheep and Goat
Productivity Improvement Program. 2008.

29. Technical Note: Pasture Recovery after Fire. Agriculture Victoria. Australia. 1995.

30. Technical Note: Protecting the Land in Dry Times. Department of sustainability and Environment. Drafted Steve Erlandsen and Peter Hamence. 2002.

31. Thompson J, Reithmuller D, Kelly D, et al. Feral Goats in South Western Queensland: a permanent component of the grazing lands. The Rangeland Journal. 2002;24(2):268-287.

32. Uribe F, Zuluaga AF, Valencia L, et al. Establecimiento y manejo de sistemas silvopastoriles. CGSpace. 2011;76. 